\title{
The 2010 Midterm Election for the US House of Representatives
}

\author{
CEFOS Working Paper 9 \\ 2010
}

Douglas A. Hibbs, Jr.

CEFOS

\begin{abstract}
The number of House seats won by the president's party at midterm elections is well explained by three pre-determined or exogenous variables: (1) the number of House seats won by the in-party at the previous on-year election, (2) the vote margin of the in-party's candidate at the previous presidential election, and (3) the average growth rate of per capita real disposable personal income during the congressional term. Given the partisan division of House seats following the 2008 on-year election, President Obama's margin of victory in 2008, and the weak growth of per capita real income during the first 6 quarters of the 111th Congress, the Democrat's chances of holding on to a House majority by winning at least 218 seats at the 2010 midterm election will depend on real income growth in the 3rd quarter of 2010. The data available at this writing indicate the that Democrats will win 211 seats, a loss of 45 from the 2008 on-year result that will put them in the minority for the 112th Congress.
\end{abstract}

\section{CEFŌS}

Centrum för forskning om offentlig sektor - Center for Public Sector Research www.cefos.gu.se 


\section{CEFOS Working Paper 9}

The 2010 Midterm Election for the US House of Representatives

(C) Douglas A. Hibbs, Jr., 2010

ISSN: 1653-3895

\section{CEFOS CEFOS}

Centrum för forskning om offentlig sektor

Göteborgs universitet

Box 720

Center for Public Sector Research Göteborg University

\section{P.O. Box 720}

40530 Göteborg

SE-405 30 Göteborg, Sweden

office@cefos.gu.se office@cefos.gu.se

Tel. 031-773 4142

www.cefos.gu.se

Tel. +46 317734142

www.cefos.gu.se 


\section{Douglas A. Hibbs, Jr.}

www.douglas-hibbs.com/house2010election22september2010.pdf

Center for Public Sector Research (CEFOS), Gothenburg University

22 September 2010r3

\section{The 2010 Midterm Election for the US House of Representatives}

Summary: The number of House seats won by the president's party at midterm elections is well explained by three pre-determined or exogenous variables: (1) the number of House seats won by the in-party at the previous on-year election, (2) the vote margin of the in-party's candidate at the previous presidential election, and (3) the average growth rate of per capita real disposable personal income during the congressional term. Given the partisan division of House seats following the 2008 on-year election, President Obama's margin of victory in 2008, and the weak growth of per capita real income during the first 6 quarters of the 111th Congress, the Democrat's chances of holding on to a House majority by winning at least 218 seats at the 2010 midterm election will depend on real income growth in the 3rd quarter of 2010. The data available at this writing indicate the that Democrats will win 211 seats, a loss of 45 from the 2008 on-year result that will put them in the minority for the 112th Congress.

Although this essay features some predictions about likely outcomes of the 2010 election for the US House of Representatives, the underlying statistical model is meant to be structural or causal and is not targeted on forecasting accuracy. My analysis draws upon founding concepts in Gerald H. Kramer's landmark 1971 Am.Pol. Sci.Rev. paper, and upon subsequent research by Edward R. Tufte, Morris P. Fiorina, John R. Hibbing and John R. Alford, Michael S. Lewis-Beck and Tom W. Rice, James E. Campbell, Robert S. Erikson, Gary C. Jacobson, Alberto Alesina and Howard Rosenthal, Kevin B. Grier and Joseph P. McGarrity, and Ray C. Fair. Measurement of economic performance best suited to statistical analysis of aggregate 
electoral outcomes is based on my 1982 Am.Pol.Q. paper on House and presidential elections, on my 1987 Harvard UP book on American Political Economy, and on my 2000 Public Choice paper on the Bread and Peace model of presidential voting. ${ }^{1}$

Most statistical models of aggregate House election outcomes focus exclusively on vote shares going to the major parties. (Research first undertaken by Michael S. Lewis-Beck and Tom W. Rice and James E. Campbell about a quarter of a century ago are notable exceptions.) But aggregate votes are mainly of academic interest. What really matters politically is the partisan division of seats, and that is the object of attention here.

\section{The Model}

I estimated the following equation for midterm House elections covering the period 1950 to 2006 (15 elections):

$$
H S_{t}=\alpha+\rho H S_{t-8}+\gamma P V_{t-8}+\beta\left(\sum_{j=1}^{7} \lambda^{j} \Delta R_{t-j} \cdot\left(1 / \sum_{j=1}^{7} \lambda^{j}\right)\right)
$$

subject to the restriction that $0 \leq \lambda \leq 1$, where

- $H S_{t}$ denotes the number of House seats won by the party of the president (the 'in-party') at midterm election quarter $t$

- $H S_{t-8}$ is the number of House seats won by the time $t$ in-party at the previous on-year election (the last presidential election), eight quarters ago at time $t-8$

- $P V_{t-8}$ is the percentage point margin of the two-party vote received by the sitting president at the previous presidential election, eight quarters ago at time $t-8$

\footnotetext{
${ }^{1}$ Citation sources of the foregoing appear at the References list below.
} 
- $\Delta R_{t-j}$ are quarter-on-quarter changes, expressed at annual percentage rates, of per capita Disposable Personal Income deflated by the Consumer Price Index $(R)$, computed $\log _{e}\left(R_{t} / R_{t-1}\right) \cdot 400$.

The autoregressive term $H S_{t-8}$ aims to pick up the net impact on the number of seats won by the in-party at midterms of the institutional advantages enjoyed by incumbents in the US's single-member district, constituency service-oriented legislative system. The magnitude of the incumbent president's vote margin in the previous presidential election, $P V_{t-8}$, captures the electorate's propensity to seek balance in partisan dominance of the executive and legislative branches of government at the first opportunity following each on-year presidential election outcome. The lag sequence $\sum \lambda^{j} \Delta R_{t-j}$ is the single most politically relevant measure of cumulative change in economic wellbeing; it registers the degree to which national economic performance affects total House seats going to the party holding the presidency at midterms, with the in-party rewarded for good and punished for bad weightedaverage growth of per capita real disposable personal income over the congressional term. $^{2}$

Estimation of (1) and small variations of it always yielded estimates of the lag sum weighting parameter $\hat{\lambda}$ bumping up against the constraint $\lambda \leq 1$, and so the model simplifies to

$$
H S_{t}=\alpha+\rho H S_{t-8}+\gamma P V_{t-8}+\beta \overline{\Delta R}_{t}
$$

\footnotetext{
${ }^{2}$ The specification is then a variant of retrospective rather than prospective political valuation of economic performance in the sense described in my essay "Voting and the Macroeconomy" in the 2006 Oxford Handbook of Political Economy. Not a shred of credible evidence supports the so-called 'rational,' purely prospective view of economic valuation and electoral choice.
} 
where $\overline{\Delta R}_{t}$ is the arithmetic average of per capita real disposable personal income growth rates over the seven quarters preceding each midterm election: $\overline{\Delta R}_{t}=$ $\sum_{j=1}^{7} \Delta R_{t-j} / 7=\log _{e}\left(R_{t-1} / R_{t-8}\right) / 7 \cdot 400$. Ordinary-least-squares estimates of $(2)$ are

\section{$\underline{\text { Table } 1}$}

Coefficient estimate: $\quad \alpha=62 \quad \rho=0.62 \quad \gamma=-1.4 \quad \beta=9.7 \quad \operatorname{adj} . R^{2}=.92$
(Std. error $\mid \mathrm{p}$-value)
$(20 \mid .01)$
$(0.09 \mid .00)$
$(0.39 \mid .00)$
(2.4|.00) $\quad R M S E=11$

Adjusted for degrees of freedom, $92 \%$ of the variation in House Seats won by the in-party at midterm elections is explained statistically by the model. That fit is as good - in fact it is better - than those delivered by equations I have seen for midterm House vote shares, and of course it has the advantage of helping explain the partisan distribution of House seats rather than votes - the former being the electoral outcome of ultimate political interest. At 435 total House members, a party caucus needs 218 members to control House organization. ${ }^{3}$ The estimates in Table 1 imply that at midterm elections the in-party is expected to win a baseline constant of 62 seats, plus a number of seats equal to about $62 \%$ of the number won at the previous onyear election (the incumbency effect), minus around 1.4 seats for every percentage point of the sitting president's vote margin in the previous on-year election (the balance effect), plus almost 10 seats for every percentage point of growth in per capita real disposable personal income over the congressional term. The upshot of

\footnotetext{
${ }^{3}$ There were 436 House seats after the 1958 midterm election (for the 86th Congress) owing to the accession of Alaska to the union on January 3 1959, and 437 seats following the 1960 on-year election (the 87th Congress) owing to the accession of Hawaii to the union on August 21 1959. Reapportionment after the 1960 census restored the total number of seats to 435 at the 1962 midterm election. At various times late-in-the-term resignations and deaths have left the House 1 or 2 seats short of 435 going into an election.
} 
these effects is depicted in the figure below graphing the time paths of actual and fitted values of House seats won by the in-party at midterm elections from 1950 .

Actual and Fitted Midterm House Election Results, 1950-2006
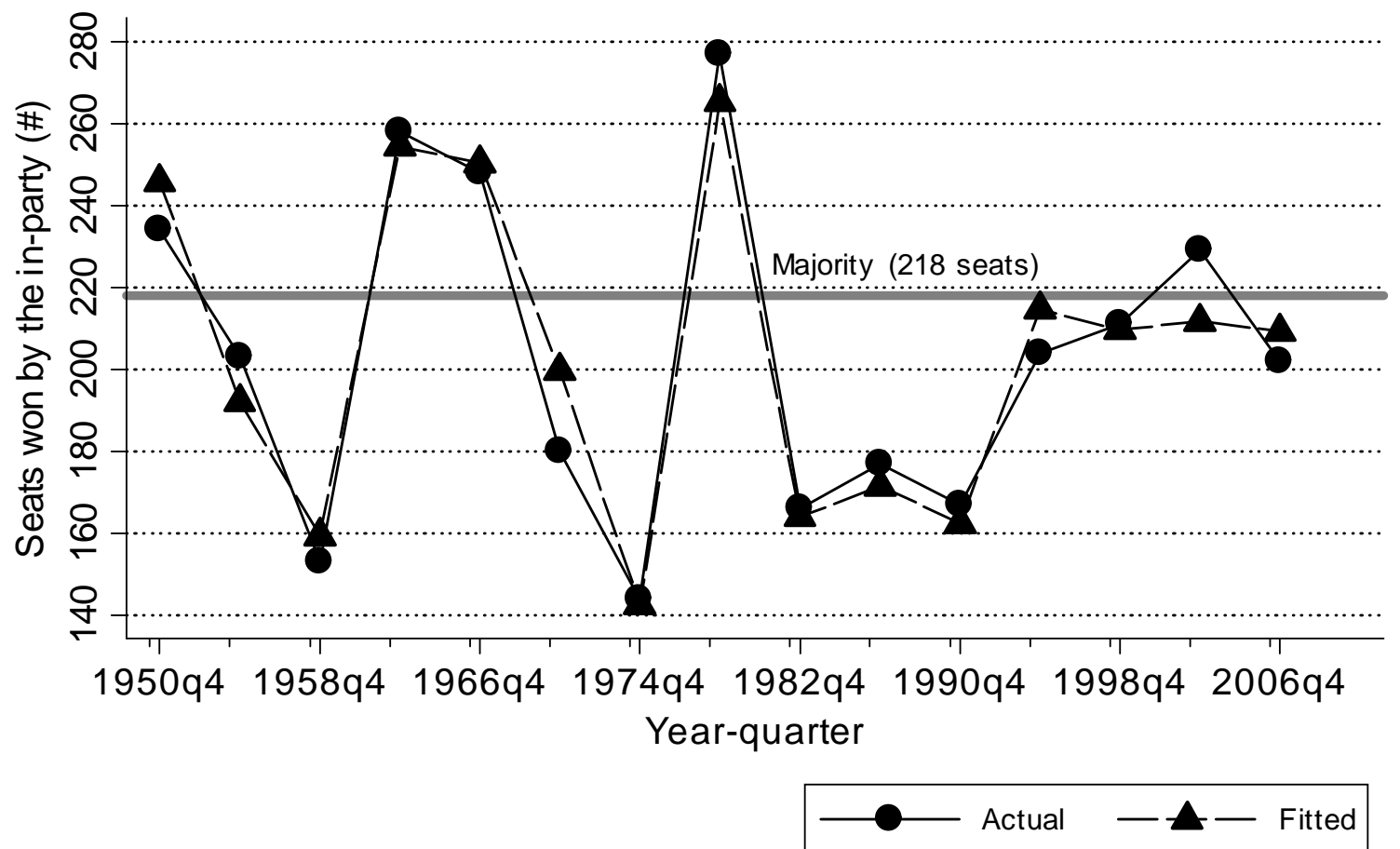

Source: www. douglas-hibbs.com

\section{Implications for 2010}

What does the model in (2) say about the likely partisan division of House seats in the 112th Congress? In the 2008 on-year election the Democrats won 256 House seats. The Democratic presidential candidate Barack Obama's margin was 
7.4 percentage points - Obama won $53.7 \%$ to McCain's $46.3 \%$ of the 2008 two-party vote. Applying the coefficient estimates in Table 1 to those predetermined values for $H S_{t-8}$ and $P V_{t-8}$ implies that average per capita real disposable personal income growth over the first seven quarters of the 111th Congress must exceed 0.8 for the in-party Democrats to hang on to a bare majority of 218 seats after the 2010 midterm election. ${ }^{4}$ Average $\Delta R$ during the first six quarters of the 111th Congress was only $0.6 \%$ - which is well below the postwar average real income growth rate at midterm elections of $1.5 \%$. Income growth during the last full quarter of the term $-2010 \mathrm{q} 3$ - will consequently have an unusually big impact on which party will command a House majority in the 112th Congress.

So what will per capita real income growth be for $2010 \mathrm{q} 3 ?^{5}$ If robust recovery from the severe recession that began in December 2007 (which helped elect Barack Obama to the presidency) is actually underway, real incomes could easily rebound sharply. Truly whopping quarterly growth rates of per capita real disposable personal incomes - exceeding even $10 \%$ on an annual basis - are entirely possible in V-shaped recoveries from a deep contractions. In fact, the Business Cycle Data Committee of the National Bureau of Economic Research announced on 20 September 2010 that the trough in business activity occurred in June 2009, marking the official end of the longest recession since the Great Depression. ${ }^{6}$ Yet more than a year after the recession's official trough the public's state of confidence - the prevailing 'animal spirts' - appears to me to be deeply pessimistic, and US policy authorities have pretty much run out of fiscal and monetary bullets that might shift short-term expectations

\footnotetext{
${ }^{4} H S_{2010}=62+.62 \cdot 256-1.4 \cdot 7.4+9.7 \cdot \overline{\Delta R} \succeq 218$ if $\overline{\Delta R}_{2010} \succeq 0.8$.

${ }^{5}$ In fact there is uncertainty about income growth during last quarter - the 2010q2. The personal income data for q2 posted by the Commerce Department's Bureau of Economic Analysis on 30 August 2010 are 'second estimates' and they are subject to potentially large revisions later. 'Third estimates' for 2010q2 are scheduled for release on 30 September 2010.

${ }^{6} \mathrm{http}: / /$ www.nber.org/cycles/sept2010.html.
} 
in a more positive direction. More important, preliminary data from the Bureau of Economic Analysis on the development of disposable personal income from June to $\mathrm{July}^{7}$ show per capita real growth in negative territory: On an annual basis the decline was almost 3 percentage points from June to July 2010. My best guess and it is just that, an informed guess - is that final data for whole quarter will be that bad, and maybe worse. Insofar as per capita growth in real disposable personal income is concerned, the United States seems to remain mired in recession. As shown

in Table 2, my model predicts that with a real income growth rate of $-3 \%$ in 2010q3 the Democrats will win 211 seats - a loss of 45 from the 2008 on-year result that will put them in the minority for the 112th Congress.

\section{Table 2}

$\begin{array}{cccccc}\Delta R \text { in 2010q3 of: } & -5 & \mathbf{- 3} & 0 & +3 & +5 \\ \begin{array}{c}\text { yields 2009q1-2010q3 } \overline{\Delta R} \text { of: } \\ \text { and predictions }\end{array} & -0.2 & \mathbf{+ 0 . 1} & +0.5 & +0.9 & +1.2 \\ \begin{array}{c}\text { Democratic Seats in 2010: } \\ \text { Seat Change from 2008: }\end{array} & -48 & \mathbf{2 1 1} & 215 & 219 & 222 \\ & -\mathbf{4 5} & -41 & -37 & -34\end{array}$

\section{Qualifications}

My prediction of the partisan division of seats for the 112th Congress shouldn't be taken too seriously. As already mentioned, there is uncertainty about what per capita real income growth will be in 2010q3 and, consequently, about what average real income growth $\overline{\Delta R}$ over the congressional term will be. Likewise there is uncertainty

\footnotetext{
${ }^{7}$ See http://www.bea.gov/newsreleases/national/pi/pinewsrelease.htm.
} 
about the true parameter values of my model, even if its functional form is spot on. For example, if the true value of the incumbency parameter $\rho$ is just 1 standard deviation below the point estimate reported in Table 1 - a value of 0.53 instead of 0.62 - the Democrats would be deep in the minority rather than narrowly in the majority for the 112th Congress, with 199 seats rather than 222, even if 2010q3 per capita real growth comes in at $+5 \%$. Moreover, the standard error of the estimated model is 11 seats, and so the +/- 1 standard deviation band (bracketing $68 \%$ of potential outcomes under the usual assumption of normally distributed random shocks) is 22 seats. On the upside, a random shock of just 1 standard error means the Democrats would hang on to a bare-bones House majority of 219 seats even if 2010q3 per capita real income growth turned out to be as poor as $-5 \%$.

The model presented in this essay is designed to explain midterm House election outcomes in terms of systematic predetermined and exogenous factors rather than to deliver optimal predictions. For that reason the model does not include trend terms or polling measurements of the public's political sentiments and voting intentions of the sort populating forecasting equations. Trends and related time-coded variables are ad-hoc, statistical junk without scientific merit no matter how much they improve statistical fits or forecasting accuracy in various samples. Polling variables are endogenous. Survey assessments of the popularity of the incumbent president, congressional vote intentions, and kindred poll measurements of political sentiments are driven by one or more of the same factors determining the partisan division of votes and seats - the institutional advantages of incumbency, the electorate's apparent propensity to seek partisan balance, average real income growth over the term, and perhaps other fundamental variables. Although equations dedicated to forecasting ought to yield pretty good predictions, they contribute little or nothing to understanding the underlying causes of election outcomes. 
The best forecasts in 2010, as in earlier elections, will almost surely be turned in by thick markets betting odds data like those generated at Intrade. ${ }^{8}$ Of course betting data tell us absolutely nothing about the root causes of electoral behavior. Instead they reveal the judgement of market participants - punters who lay money on the table (sometimes very big money) and accordingly have strong incentive to process efficiently all available information relevant to predicting election outcomes.

\section{References}

Alesina, Alberto, and Howard Rosenthal. 1989. "Partisan Cycles in Congressional Elections and the Macroeconomy." American Political Science Review 83(2): 373-98.

Campbell, James E. 1985. "Explaining Presidential Losses in Midterm Congressional Elections." Journal of Politics 47(4): 1140-57.

Campbell, James E. 1991. "The Presidential Surge and its Midterm Decline in Congressional Elections 1868-1988." Journal of Politics 53(2): 477-87.

Erikson, Robert S. 1988. "The Puzzle of Midterm Loss." Journal of Politics 50(4): 1011-29.

Erikson, Robert S. 1990. "Economic Conditions and the Congressional Vote: A Review of the Macrolevel Evidence." American Journal of Political Science 34(2): 373-99.

Fair, Ray C. 2009. "Presidential and Congressional Vote-Share Equations." American Journal of Political Science 53(1): 55-72.

\footnotetext{
${ }^{8} \mathrm{http}: / /$ www.intrade.com/jsp/intrade/contractSearch/

At this writing - 22 September 2010 - the betting odds at Intrade puts the probability at .27 that the Democrats will lose less that 39 seats and retain a House majority.
} 
Fiorina, Morris P. 1977. Congress-keystone of the Washington Establishment. New Haven, Conn.: Yale University Press.

Fiorina, Morris P. 1978. "Economic Retrospective Voting in American National Elections: A Micro-Analysis." American Journal of Political Science 22: 426-443.

Grier, Kevin B., and Joseph P. McGarrity. 2002. "Presidential Party, Incumbency, and the Effects of Economic Fluctuations on House Elections." Public Choice 110: $143-62$.

Hibbing, John R. and John R. Alford. 1981. "The Electoral Impact of Economic Conditions: Who is Held Responsible?" American Journal of Political Science 25(3): 423-439

Hibbs, Douglas A. 1982. "President Reagan's Mandate from the 1980 Elections: A Shift to the Right?" American Politics Quarterly 10(4): 387-420.

Hibbs, Douglas A. 1987. The American Political Economy: Macroeconomics and Electoral Politics. Cambridge, MA: Harvard University Press.

Hibbs, Douglas A. 2000. "Bread and Peace Voting in U.S. Presidential Elections." Public Choice 104: 149-80.

Hibbs, Douglas A. 2006. "Voting and the Macroeconomy." In B. Weingast and D. Wittman, Eds. The Oxford Handbook of Political Economy, Oxford University Press, chapter 31:565-586.

Jacobson, Gary C. 1990. "Does the Economy Matter in Midterm Elections?" American Journal of Political Science 34(2): 400-04.

Kramer, Gerald H. 1971. "Short-Term Fluctuations in U.S. Voting Behavior, 18961964." The American Political Science Review 65(1): 131-43. 
Lewis-Beck, Michael S., and Tom W. Rice. 1984. "Forecasting U. S. House Elections." Legislative Studies Quarterly 9(3): 475-486.

Tufte, Edward R. 1975. "Determinants of the Outcomes of Midterm Congressional Elections." American Political Science Review 69(3): 812-26. 